\title{
THE ACQUISITION OF NOUNS AND VERBS OF MANDAILINGNESE \\ BY TWO - YEAR-OLD MANDAILING CHILDREN
}

\begin{abstract}
By
Marwah, M.Hum ${ }^{1}$

ABSTRAK

Pemerolehan Kata Benda dan Kata Kerja dalam Bahasa Mandailing oleh Anak Anak Mandailing Usia Dua Tahun. Penelitian ini focus dalam menggambarkan pemerolehan kata benda dan kata kerja bahasa mandailing yang diperoleh anak usia dua tahun. Penelitian ini berlokasi di Jambur Padang Matinggi, Panyabungan Utara, Mandailing Natal dan subjek dalam penelitian ini adalah anak usia dua tahun. Dalam mengumpulkan data peneliti menggunakan observasi partisipant dan sebagai alat pengumpul data menggunakan audio visual. Tekhnik data analisis menggunakan descriptive qualitative.data tersebut di deskriptipkan melalui proses transkrip. Penemuan pertama anak memeperoleh kata benda 140 dan 86 kata kerja and jenis kata benda yang diperoleh subjek didominasikan common nouns. Kedua, anak anak memperoleh kata benda dan kata kerja ketika pengasuhan dirumah, dan bermain dalam lingkungan.
\end{abstract}

Kata kunci: pemerolehan bahasa, kata benda, kata kerja.

\section{A. INTRODUCTION}

Interaction a child is born with having knowledge about any single world. She or the acquires the language through a process of acquiring, starting immediately from birth (Clark, 2003)This acquiring process of course is not done as a formal way which is always conducted in the class where the baby learns any field of subject by the help of the teacher. It means that the child acquires the language with their own ability without the process of teaching.

A child is an individual who spends most of his time for learning. Therefore a common statement in society told that childhood is a time when a child spends mostly with studying and observing everything new in his/her life. That learning session is a process of studying and structuring language in which they will need

\footnotetext{
${ }^{1}$ Writer is an English Department Lecturer of Tarbiyah and Teacher Training Faculty (FTIK), Institute for Islamic Studies (IAIN) Padangsidimpuan.
} 
to interact with society around them. Learning for a child does mean like learning at school but learning means the process of acquiring the language.

Infants discriminate and produce sounds that are absent from the languages they are hearing (David and ManNeilage, 1995 ; Kent, 2000). It means children produce sound what they are hearing. Before he produces spoken words, a children in his life utters very limited and simple utterances based on the things he sees, feels, and hears which are researcher search data the process of language acquisition how they can acquire it a word pronounced by aged two year ol the children learns to produce the word whether noun or verb.

The acquisition of children might also be affected by the properties of each language. For example the language feature could influence the order in which children acquire each system of the language and could also make same parts of the language harder or easier to acquire. The acquisition could also be affected by the social of interaction and cognitive development.

When children learn a first language, they could build on preexisting notions of what to represent with knowledge as well as prior notions of communications, of children start to learn the language from having no words at all till they can discover what is represented in language (Clark, 2003). It means that the language acquired by the children is done by their own selves and they can do it by help of their surrounding environment.

Every child has different cognitive development. It means even at the same age they do not have the same abilities in acquiring nouns or verbs. Their abilities are different in acquiring nouns and verbs in their lives and beside that their abilities influenced by two factors, namely internal and external factors.

One of the requirement in the process of the studying a child's language acquisition is to understand the child's family backround. Its important fact to be studied so that the development can be well understood and will give a great deal of contribution to the process of a child's mental development.

One of the experts of the language acquisition says that the language acquisition for all over the world is the some at each chronological age along the development of language (Kormos, 2006). It means at each the acquisition of the language by the children normally have the same stages namely at the age of four 
months, the children start babbling. At the age twelve to eighteen months is their early words, commands and responding to "no". One can predict what development features should be present A fourteen- month-old child, for example, may utter/naena/for banana, while the two-year-old child may say /naena/,and the three-year-old child may finally say banana.

Dardjowidjoyo (2000:87) states about 1,6 year, the child will start to put togather two successive single words, eg. "momma......nnum" which means "mama minum". In these ages $1 ; 5$ and 1;7, the child produces words for object increasinly (clark, 2003:87). And Menyuk (1961:63) says that the priod during which one word or two word sentences are beginning to be used and symmmetries observed in friquency and after this priod, it may idicate a recycling of the developmental process. At 24 to 27 months the children have total vocabularies of 300 to 400 words. They produce two or three words phrase. It should be remembered that during the period or 18 to 27 months, the children have progressed from produce single word to produce two to three word phrases.

Around age two, children combine words and gestures and produce their first word combination. The child has vocabularies of about 400 words. The child produces many single utterances, such as namely object, as well as two and three word, sentences which express the semantic concept that are usually contained a single clause, for example " mommy milk" probably mean " mommy get some milks to drink" (clark, 2003: 6).

Theoritically, a two year old child is expected to acquire children combine words and gestures and produce their first word combination. However, this acquisition das not occur to yhe present children as the data source of the study. Thus it needs studying how and why their acquisition the way its.

These examples language acquired by children. the child ask to "lit up " she take vale and cloth for rocking the baby (kain gendong) and then say "ompa " to say "buka"is "bupa","num", is "num","susu", is "cucu. " those are at the same ages, but they come from different family background. If child want to drink, child go to dispenser and hold dispenser say nim. If child want to out child take vale and then say ilbab. This is one of the ways in which a child is trying to communicate with the environment. 
Table 1.1.These example of nouns acquisition by children:

\begin{tabular}{llll}
\hline No & $\begin{array}{l}\text { Utterances mandailing } \\
\text { Children of nouns }\end{array}$ & Indonesian & English \\
\hline 1 & Ilbab & Jilbab & Vale \\
2 & Cucu & Susu & Milk \\
3 & Tek & Etek & Aunt \\
\hline
\end{tabular}

Table 1.2 These example of verbs acquisition by children:

\begin{tabular}{llll}
\hline No & $\begin{array}{l}\text { Utterances mandailing } \\
\text { Children of verbs }\end{array}$ & Indonesian & English \\
\hline 1 & Ompa & Gendong & Carry \\
2 & Num & Minum & Drink \\
3 & Bupa & Buka & Open \\
4 & Mam & Makan & Eat \\
\hline
\end{tabular}

From this phenomenon it can be known that a child seems to have their own words by simplifying the way of adult in expressing a word, which they each as the input of their phonology system, whenever they got a difficulty in pronouncing well the adult's word. Though child's word is different from adult's, yet they share the same ways. The writer then believes that investigate in this phonological issue trough the word production of a child is interesting to do. Thus, kind of case is the main background for this study to be observed.

In order to do this study, the researcher observes two-year old mandailing children. Because the researcher and her husband, from one ethnic, it is mandailing. So the researcher hopes her son can use mandailing. Because of that do this research. The research observes her son and sister in law's son and the environment has not well in pronunciation. Two year-old children has been observed. For that purpose, an intended person for the subject of this study should be found. His name is rabiatul adawiyah and ahmad reza, he is a Mandailingnese. The researcher is very curious to observe the acquisition of words specifically the acquisition of nouns and verbs, and discover whether two children differ in the terms of the total number of verbs and nouns. Therefore this study seeks to answer types of nouns and verbs and the context acquired nouns and verbs by two year old mandaling children. 


\section{B. RESEARCH METHOD}

This study will be conducted by applying qualitative research design Bogdan\&Biklen [9]. state that qualitative research is frequently called naturalistic because the researcher frequents places the event he or shenis interest in natural occur. Qualitative research is characterized by describing in words rather than numbers, by exploring to find what is significant in the situation, by trying to understand and explain it, by beginning without structure but structuring the research as proceeds (inductive) and by working in natural situation.

Bogdan and Biklen [9] assert that [9] descriptive means the data collected in the form of words rather than number. Descriptive qualitative tried to analyze the data with all their richness as possible to the form in which the researcher record and transcribe and the written result of the research contain quotation from the data to illustrate and substantiate the presentation.

The problems are about acquisition of nouns and verbs by two year old mandailing children. The types of this study is the observational the data are gathered by applying participant observation. The focus of this studyis to identify the mandailing words acquired by two year old mandailingchildren in which the data are collected through (participant) observation.

The subject of this study are two year old mandailing children. According to Mashun[10] there are some criteria to get the presentative data, to choose the respondents as subject of a research base on: age, sex have education and different background of family situation. The subjects is writer's son and sister in law's son of writer. children live researcher's house and they always play with their friends at the same ages in front of researcher's house. this is the reason why researcher decided to choose those children. His name is RA and AR.

While the objects of this research are utterances of mandailingnese of nouns and verbs by two year old mandailing children. The researcher collect the data for three months. The techniques of collecting data that is used is(participant) observation and interview. The observation by recording the activity of the children several minutes. 
Base on the technique of data is used in this research the researcher use digital camera, schedule field notes and audio taping. The digital camera is revealed in the brief moments to paper and after studying. In order to make subject want to speak, the reseacher tempted them by showing snack and fruits.

The data will be analyzed by interactive model classified officially Miles, Huberman \& Saldana[11] In this analysis, it is by ongoing analysis and after collecting the entire the data (Miles, Huberman \& Saldana, 2014). Purpose an analysis as three concurrent flowed of activity: (1) data condensation, (2) data display, and (3) conclusion drawing / verification.

C. FINDINGS AND DISCUSSIONS

Types of Nouns and verbs Acquired by Children

Table 1.1: types of nouns acquired by subjects

\begin{tabular}{llllll}
\hline No & Types of nouns & Subjects 1 & $\%$ & Subjects \\
& & Subject 2 & $\%$ \\
\hline 1 & Common noun & 55 & 82 & 57 & 78 \\
2 & Proper noun & 7 & 10,4 & 9 & 12,3 \\
3 & Collective noun & - & - & - & - \\
4 & Pronoun & 5 & 7,5 & 7 & 9,5 \\
\hline Total & 67 & $100 \%$ & 73 & $100 \%$ \\
\hline
\end{tabular}

\begin{tabular}{llcccc}
\hline No & Types of verbs & \multicolumn{4}{c}{ Subjects } \\
\cline { 3 - 6 } & & Subjects 1 & $\%$ & Subject 2 & $\%$ \\
\hline 1 & Transititive & 35 & 83,3 & 35 & 79,5 \\
2 & Interansitive & 7 & 16,6 & 9 & 20,5 \\
\hline
\end{tabular}

The first nouns, S1 acquired common nouns 82\%, proper noun 10,4\%, pronoun $7,5 \%$. It means common nouns acquired by children more than proper nouns and pronouns. S2 common nouns $78 \%$, proper noun $12,3 \%$, pronoun $9,5 \%$. It means common nouns acquired by children more than proper nouns and pronouns also. The second, table 4.4 indicates that the types of verbs, S1 acquired transitive $83,3 \%$, and intransitive $16,6 \%$. And $\mathrm{S} 2$ acquired transitive 79,5\%, and intransitive $20,5 \%$. Its means transitive acquired by children more than intransitive. 
The resulting of the word produced majority of types of nouns is common noun and not found collective noun. It is because the these children more quickly respond to things were common noun than collective noun. Common noun easy to learn by children than collective noun especially two year old children that seldom go out from house and communicate with other people meanwhile hear only. So types of nouns were acquired by two year old children in mandailingnese were dominated common noun not found collective noun.

\section{Playing at environment}

As a children play and work, they do so through language (garcia, 1994; lindfors, 1991;) play is a way for children to extend their langauge abilities; it is where new vocabulary can be introduced as well as new ways to use it.it also allows children opportunities to express their poit of view, solve disagreements, and persuade peers to work togather. Language play has afocus on the very langauge elements that children will need to consider later when learn about language.

Children acquired mandailingnese when playing with environment such frinds neighbord. Subjects acquired from relatives and friends when they played and talked with them in their daily activities, actually they were make interaction with subject, and subject try to understandable what they talk and play with them. Such as his friend say " buat olamu "/take your ball. And then he answer, "olo/ yes, mayam ita/ we are plying" . it can be oncluded that the RF acquired nouns and verbs of mandailingnese when playing with his friends in front of house. RA said " yo opung/ come grand mother" RF answered " boang ita/ we across ". It can be concluded that RA nad RF acquired nouns and verbs of mandailingnese when playing with their friends. so to sum of the context of language acquired of mandailingnese when playing at environment.

So based on observation, it is clear that the context nouns and verbs acquired by children were caregiven at home and playing at environment. But dominated when playing at environment. The result of findings in this research, the subjects made incorrect pronounciations that made the researcher fell confuse and the subject also produced unclear meaning that also confused the researcher. 
In this research, the subject are RF and RA, they are two-year-old Mandailing children. The first finding is the subjects produced nouns and verbs. The first nouns, S1 acquired common nouns $82 \%$, proper noun $10,4 \%$, pronoun $7,5 \%$. It means common nouns acquired by children more than proper nouns and pronouns. S2 common nouns $78 \%$, proper noun $12,3 \%$, pronoun $9,5 \%$. It means common nouns acquired by children more than proper nouns and pronouns also.

The second, table 4.4 indicates that the types of verbs, S1 acquired transitive $83,3 \%$, and intransitive $16,6 \%$. And S2 acquired transitive 79,5\%, and intransitive 20,5\%. Its means transitive acquired by children more than intransitive. RF and RA produce nouns 140, where 112 common nouns, 16 proper nouns, 12 pronoun. Beside that, in producing verbs those subjects produced verbs RF and RA produced 86 verbs, where 70 transitive, 16 intransitive. So the total of nouns and verbs acquired by children were 226 . Based on the analysis can be seen that nouns of Mandailingnese were acquired by two-year-old Mandailing children were dominated by common nouns. The second finding, the children got the language while process care at home, playing at environment, Based on the observation children acquired nouns and verbs while playing at environment. the subjects sometimes used body language when they talked and played with their family members, because her mother use body language with their child. Potential children acquired language. However the acquisition of nouns and verbs are fasilitate and speeded by verbal increasing in contextual situation. The increasing is motivate by child caresive. The third finding, the subjects sometimes produces incorrect pronunciations because their parents usually introduced pronunciation when the subject's parents talked with them. base on observation and the child got language from parents but that dominant from surrounding.

In producing verbs and nouns of Mandailingnese words, subjects made substitutions and omissions that confused the researcher when did an observation. The subjects acquired verbs and nouns from their parents, relatives and friends when they played and talked with them in their daily activities. And the children got language from their family and surrounding.

The first research problem of the research is "what types of nouns and verbs of manadailingnese are acquired by two-year-old mandailing children?"the 
finding is the types of nouns acquired by children dominantly are common noun not found collective noun because the children are quickly to response the common noun that common noun is a kind of easy word to be learned by children especially at two year old children moreover common nouns is often use in daily activities. And they are have different varieties of common nouns acquired each of subjects because they are different background of the parents of them.

The second research problem of this research is "in what context are nouns and verbs of mandailingnese acquired? "The third finding, the children got the language while process care at home, and plying at environment. the subjects sometimes used body language when they talked and played with their family members, because her mother use body language with their child. Actually, children acquired nouns and verbs more often when plying at environment. The research finding of Puadi (2016), said that language acquired just from family because they cannot socialize with the children in their surroundings because they only are in the house not so socialize with other children. It makes the research finding of this reserch with Puadi (2016) finding have different in acquire language. And they have diffrent context in acquired nouns and verbs that each different job of the parents of them, so the time for child different also, it made them different context.

\section{CONCLUSION}

Childrens's acquisition is dominated by noun or common nouns, this is indicated that more than $70 \%$ are acquired by children. its means common nouns acquired by children more than proper nouns and pronouns. And the types of verbs, S1 acquired transitive 83,3\%, and intransitive 16,6\%. And S2 acquired transitive $79,5 \%$, and intransitive $20,5 \%$. Its means transitive acquired by children more than intransitive. RF and RA produce nouns 140, where 112 common nouns, 16 proper nouns, 12 pronoun. Beside that, in producing verbs those subjects produced verbs RF and RA produced 86 verbs, where 70 transitive, 16 intransitive. So the total of nouns and verbs acquired by children were 226. Based on the analysis can be seen that nouns of Mandailingnese were acquired by twoyear-old Mandailing children were dominated by common nouns. 
The researcher concluded that the subjects acquired Mandailingnese verbs and nouns while care at home, playing at environment, whether they were influenced by their family members and friends. Beside that, the subjects sometimes used body language when they talked and played with their friends and family members to tell with actually in their heart and mind. Because his parents/caresive often use body language in interaction

\section{REFERENCES}

Clark, E. V. 2003. First Language Acquisition. Cambridge: University. Press.

David and ManNeilage, 1995 ; Kent, 2000).

Kormos,J. Speech production and second language acquisition: Method, descriptive, and explanation. Cambridge: cambridge University.

Dardjowidjojo, sudjono, 2000. ECHA: Kisah Pemerolehan Bahasa Anak Indonesia. Jakarta: Grasindo Jaya.

Menyuk, P 1971. The Acquisition and Development of Language. Massachutestts Institute of Technology

Purnamawaty, the acquisition of nouns and verbs by two year old indonesian children.state university of Medan,2015.

Wildan, the first language phonology acquisition by two year old mandailing child. state university of Medan. 2013.

Winner.the acquisition of Indonesian Verbs and ddNouns by two year old batak toba children. . state university of Medan. 2013.

Bogdan R. C. \& Biklen. S. K. 1992. Qualitative Research For Education (2 ${ }^{\text {nd }}$ E). Boston. Allan \& Bacon.

Mashun (2005)

Miles, Huberman \& Saldana (2014) 